$\odot$

|||

\title{
JĘZYK AGRESJI U DZIECI Z RODZIN DYSFUNKCYJNYCH
}

ABSTRACT. Aleksandra Sileńska, Kamila Szpunar, Język agresji u dzieciz rodzin dysfunkcyjnych [Children's language of aggression from dysfunctional families] edited by M. Obrębska, L. Bakiera, "Człowiek i Społeczeństwo" vol. L: Psychologiczne konteksty komunikacji interpersonalnej [Psychological contexts of interpersonal communication], Poznań 2020, pp. 117-126, Adam Mickiewicz University. ISSN 02393271, https://doi.org/10.14746/cis.2020.50.8.

Language of aggression, which is the subject of this article, is closely linked with the concept of aggression. Aggression is understood as any form of behaviour directed at causing damage or causing injury to another living creature. The article presents a pilot study about aggressive language and behaviour of children from dysfunctional families. Sample consisted of 12 children, aged 7 through 12, from dysfunctional families. Competent referees made observation of children's language and behaviour using observation questionnaire. The observation took part during their activities at a community day care social centre. The result showed that referees agreed that the children from the study sample often used aggressive language and behave aggressively. There is a lack of this kind of studies.

Keywords: aggressive language, aggressive behaviour, children, adolescents

Aleksandra Sileńska, Uniwersytet Szczeciński, Instytut Psychologii, ul. Krakowska 69, 71-017 Szczecin, silenska.a@gmail.com, ORCID: https://orcid.org/0000-0003-3169-8467.

Kamila Szpunar, Uniwersytet Szczeciński, Instytut Psychologii, ul. Krakowska 69, 71-017 Szczecin, kamilaszpunar@wp.pl, ORCID: https://orcid.org/0000-0003-1817-9902. 
Granice mojego języka sq granicami mojego świata.

Ludwig Wittgenstein

\section{Wprowadzenie}

Rozważania na temat języka mają bogatą historię. Wraz z upływem lat pojawiało się coraz więcej koncepcji dotyczących tego, jaką funkcję w naszym życiu pełni język i dlaczego ludzie, nawet w obrębie jednej narodowości, posługują się nim w tak różnorodny sposób. Według jednej z definicji języka stanowi on system symboli zorganizowany według określonych reguł. Za jego pośrednictwem odbieramy, wyrażamy i interpretujemy informacje (Morreale, Spitzberg i Barge, 2008). Przywołany na wstępie passus z Traktatu logiczno-filozoficznego z kolei nasuwa na myśl, że język stanowi odzwierciedlenie tego, jak postrzegamy rzeczywistość. Według takiego sposobu rozumienia roli języka nie jest on wyłącznie narzędziem czy uzewnętrznionym instrumentem w służbie człowieka, lecz czymś znacznie głębszym i bardziej wartościowym (Gajda, 2002). Sposób, w jaki posługujemy się językiem, oddziałuje na to, co spostrzegamy i jak się zachowujemy, a forma jego użycia zależy od ludzi, wśród których żyjemy, i zawartej między nimi umowy społecznej (Adler, Rosenfeld i Proctor II, 2007).

Język agresji, o którym traktuje niniejszy artykuł, jest ściśle powiązany z pojęciem agresji - rozumianej jako każda forma zachowania ukierunkowana na wyrządzenie szkody lub spowodowanie obrażeń innej żywej istoty (Krahé, 2005). Język agresji nie doczekał się jeszcze jednej spójnej definicji, a w literaturze można spotkać różne sposoby jego charakteryzowania. Jedno z ujęć wskazuje, że z językiem agresji mamy do czynienia wówczas, gdy określonemu komunikatowi towarzyszą negatywne emocje i intencje (Majchrzyk, 2002). Oznacza to, że o mowie agresji nie świadczą konkretne słowa, lecz sposób ich użycia. Z kolei Peisert (2004), pisząc o agresji werbalnej, zwraca uwagę na to, że przejawia się ona zwykle poprzez ciąg aktów mowy i dlatego ma charakter interakcyjno-interpersonalny. Zgodnie z prototypowym modelem wypowiedzi, zachowanie i reakcja osoby atakowanej - odbiorcy komunikatu, stymulują dalsze działania agresora - nadawcy komunikatu, nawet gdy odbiorca w odpowiedzi na atak zachowuje milczenie bądź na nią nie reaguje (Taras, 2013). 
W literaturze wyróżnia się trzy główne odmiany środków agresji językowej: agresję eksplicytną (będącą najbardziej bezpośrednią i spontaniczną formą agresji słownej), agresję manipulacyjną (o charakterze instrumentalnym, związaną z określoną ideologią, np. stygmatyzowanie czy etykietowanie) oraz agresję implicytną (wyrażającą negatywne emocje w sposób pośredni, zamaskowany) (Gajda, 2002).

Wypowiedzi agresywne, w zależności od sytuacji, pełnią różne funkcje. Pereświet-Sołtan (2013), analizując wypowiedzi pojawiające się w mediach, wskazuje, że język agresji pozwala zaspokoić potrzebę przynależności i identyfikacji z grupą. Aktom agresji często towarzyszy scalające członków danej grupy poczucie siły i odrębności względem tych osób, które mają odmienne zdanie. Co więcej, posługiwanie się językiem agresji umożliwia jednostce polepszenie samopoczucia (Majchrzyk, 2002). Krytykowanie, wyśmiewanie czy też obrażanie innych stwarza pozorne poczucie siły, kontroli oraz wyższości nad innymi. W połączeniu z wcześniej wspomnianą identyfikacją z grupą może doprowadzić do nasilenia agresji werbalnej i wykształcenia przekonania o skuteczności tego typu zachowań. Kolejnym przykładem jest posługiwanie się językiem agresji w celu obrony wyznawanych wartości (Peisert, 2004). Gdy jednostka poczuje się zaatakowana ze względu na swoje przekonania czy ideały, może to wywołać w niej silne wzburzenie. Wzrastające napięcie nierzadko inicjuje wypowiedzi agresywne, których celem jest obrona własnego zdania, ale też zniwelowanie odczuwanego napięcia. W takich sytuacjach obie strony naprzemiennie wcielające się w role sprawcy i ofiary agresji werbalnej mogą nigdy nie dojść do porozumienia. Cechuje je bowiem dychotomiczna ocena sytuacji, przejawiająca się w myśleniu, że albo ktoś jest po mojej stronie, albo jest moim wrogiem. Mowa agresji może być także sposobem na uzasadnienie wyrządzonej przykrości - kiedy jednostka, która czuje się z jakiegoś powodu poszkodowana, dopuszcza się agresji werbalnej w celu zadośćuczynienia swojej krzywdzie (Pereświet-Sołtan, 2013).

Do funkcji języka agresji zaliczamy również chęć rozładowania negatywnych odczuć (np. gniewu, frustracji), a także zdeprecjonowanie odbiorcy (np. poprzez stosowanie obraźliwych wyrazów czy wyrządzenie mu innego rodzaju krzywdy). Ponadto, agresywne środki językowe stosuje się w celu uzyskania dominującej pozycji w grupie, zdobycia statusu i prestiżu czy przyciągnięcia uwagi odbiorców (Peisert, 2004). Wielość funkcji spełnianych przez wypowiedzi agresywne wskazuje na różnorodność sytuacji, w jakich mogą zostać i są wykorzystywane. Duża moc oddziaływania agresywnych wypowiedzi powoduje, że obserwuje się je wśród osób 
reprezentujących różne grupy społeczne i zawodowe, a także wśród przedstawicieli wszystkich grup wiekowych.

Posługiwanie się środkami językowymi świadczącymi o agresji przez osoby dorosłe często nie wzbudza zdziwienia. Czasami można wręcz odnieść wrażenie, że istnieje społeczne przyzwolenie na posługiwanie się takim językiem przez osoby pełnoletnie. Zupełnie inaczej reagujemy na przejawy językowej agresji wśród dzieci, u których każdy akt agresji werbalnej powinien spotkać się z krytyką dorosłych. Przyczyn używania przez dzieci języka agresji jest wiele i często współgrają one z powodami występowania innych form agresji wśród najmłodszych. Każdy etap rozwoju człowieka niesie zagrożenia, które w przyszłości mogą doprowadzić do rozwoju zachowań agresywnych, w tym również agresji językowej. Obserwując zachowania dzieci w toku rozwoju, można zauważyć różnice w częstości i intencjonalności przejawianych aktów agresji (Brzezińska i Hornowska, 2004). Choć rozwój jednostki zawsze należy analizować przez pryzmat płaszczyzny biologicznej, socjologicznej, kulturowej i psychologicznej, to w przypadku zachowań agresywnych największy nacisk kładzie się na wpływ otoczenia rodzinnego, w którym rozwija się człowiek. Rodzina jest bowiem naturalnym środowiskiem, w którym zdobywamy wiedzę o świecie, podstawowe umiejętności, nabywamy określone wzorce zachowania i rozwijamy swój system wartości.

Każda rodzina przechodzi przez określone etapy rozwoju, które wyznaczają cykl życia rodzinnego (Ostoja-Zawadzka, 1999). Zachodzące w niej znaczące wydarzenia (np. zawarcie małżeństwa, pojawienie się pierwszego dziecka itp.) oraz sposób ich przeżywania determinują tempo rodzinnych przemian i wpływają na możliwości zachowania wewnętrznej homeostazy. W trakcie rozwoju niejednokrotnie dochodzi do kryzysów rodzinnych, które zaburzają panującą w niej równowagę i przyczyniają się do zaistnienia przejściowej dezorganizacji (Kubacka-Jasiecka, 2009). Chwilowych dysfunkcji doświadcza większość rodzin, są one bowiem częścią ich dojrzewania. Dopiero gdy dysfunkcyjność przybierze postać poważnych trudności (takich jak np. uzależnienie, przemoc, problemy emocjonalne czy finansowe) i uniemożliwione zostaje zaspokojenie podstawowych potrzeb członków rodziny, możemy mówić o rodzinie dysfunkcyjnej (Ryś, 2003).

Rozpatrując rodzinę w kategoriach systemu, zwraca się uwagę na jej strukturę, w której każda osoba zajmuje określone miejsce i pełni konkretne funkcje (Prajsner, 2002). Charakterystyczne relacje zachodzące między członkami rodziny, sposób sprawowania władzy i kontroli, a także specyficzne metody porozumiewania się pozwalają wyznaczyć granice systemu. 
Dzięki granicom rodzina może bronić swojej autonomii, a jednocześnie nawiązywać relacje z otoczeniem (Ryś, 2003). To właśnie specyfika granic systemu rodzinnego jest jednym z elementów umożliwiających rozpoznanie, czy mamy do czynienia z rodziną dysfunkcyjną. W systemach dysfunkcyjnych bowiem granice często są zatarte lub sztywne i nieprzepuszczalne, przez co uniemożliwiają nawiązywanie odpowiednich interakcji z innymi oraz zaspokajanie potrzeb i pełnienie konkretnych ról przez jej członków.

Do najczęściej wymienianych cech charakteryzujących rodziny dysfunkcyjne zaliczamy:

- odizolowanie od świata zewnętrznego i zamknięcie systemu rodzinnego w obrębie własnych granic;

- brak szczerości i otwartości w dzieleniu się własnymi odczuciami między członkami systemu, co prowadzi do zafałszowania rzeczywistości rodzinnej;

- brak współpracy, wzajemnej pomocy między elementami systemu i ukierunkowywanie się na realizację własnych celów; ignorowanie potrzeb innych członków;

- nieadekwatny sposób postrzegania świata i rzeczywistości oraz nieelastyczny podział ról rodzinnych (Ryś, 2003).

Każda rodzina, będąc systemem składającym się z poszczególnych członków i relacji między nimi, posiada własne sposoby porozumiewania się (Adler, Rosenfeld i Proctor II, 2007). Język, którym posługują się dzieci, jest w dużej mierze ukształtowany przez środowisko rodzinne, co można zaobserwować już od wczesnych lat życia. Dziecko na etapie opanowywania języka bazuje na tym, co mówią osoby dorosłe z jej otoczenia (Kielar-Turska i Białecka-Pikul, 2011). Wraz z upływem lat proces ten ulega rozwojowi, a obserwowanie najbliższych osób w różnych sytuacjach życiowych przyczynia się do utrwalania u dzieci konkretnych wzorów zachowań, a także wzorców werbalnych (Goetz, 2014). Dorastanie dzieci i przyjmowanie nowych ról społecznych (np. roli ucznia) sprzyja nawiązywaniu nowych kontaktów i przyswajaniu kolejnych form reagowania i zachowania. Stosowanie środków językowych świadczących o agresji wśród dzieci i młodzieży wobec rówieśników bardzo często wynika z chęci ustalenia pozycji w grupie lub rozładowania napięcia. Brak wiedzy wyniesionej z domu na temat konstruktywnych sposobów rozwiązywania różnych sytuacji, a zwłaszcza sytuacji konfliktowych, przyczynia się do występowania wśród dzieci agresji językowej.

W niniejszym artykule przyjrzymy się, jakie środki językowe świadczące o agresji stosowane są przez dzieci z rodzin dysfunkcyjnych. W badaniu wykorzystano klasyfikację Stanisława Gajdy (2002), który do najczęściej 
stosowanych i najbardziej dotkliwych agresywnych środków werbalnych zalicza: podniesiony ton głosu, przyspieszone tempo mowy, rozkazujący ton, ironię, drwinę lub szyderstwo połączone ze śmiechem, przekrzykiwanie, przerywanie w pół słowa, niedomówienie, przedrzeźnianie.

\section{Metoda i wyniki}

Grupy obserwowanych dzieci pochodziły z rodzin dysfunkcyjnych i liczyły po 12 osób. Dzieci były w wieku od 7 do 12 lat. Na podstawie dokumentacji prowadzonej przez kierowników świetlic środowiskowych stwierdzono, że wychowankowie z obu badanych grup, liczących łącznie 24 osoby, reprezentowały 14 rodzin. Liczba dzieci w badanych systemach rodzinnych wynosiła od minimum 2 do 8 osób. Wszystkie rodziny ze względu na trudną sytuację finansową stale korzystają z pomocy opieki społecznej, a także programów dożywiania realizowanych przez szkołę oraz organizację Caritas. Mieszkania przez nie zajmowane liczą sobie maksymalnie trzy pokoje, co nierzadko wyklucza możliwość zapewnienia dzieciom intymności i spokojnych warunków do nauki czy zabawy. Stanowi to jeden z podstawowych motywów zapisywania dzieci do świetlic środowiskowych, w których mają zapewnione nie tylko miejsce do pracy, ale również pomoc w odrabianiu lekcji. W 10 na 14 rodzin aktywny zawodowo jest tylko jeden z opiekunów i zawsze jest to mężczyzna. Spośród 14 opisywanych systemów tylko w dwóch dzieci mieszkają wraz z rodzicami biologicznymi. W pozostałych opiekunowie samotnie wychowują dzieci lub są to rodziny rekonstruowane.

Badanie przeprowadzono z udziałem sędziów kompetentnych. Ich zadanie polegało na kontrolowanej obserwacji dzieci podczas zajęć w świetlicy środowiskowej. Przed przystąpieniem do obserwacji sędziowie zostali zapoznani z kwestionariuszem obserwacji, przygotowanym specjalnie na potrzeby badania. Kwestionariusz składał się z dwóch części. Pierwsza z nich dotyczyła oceny środków językowych opartych na klasyfikacji Gajdy. Sędziowie mieli do dyspozycji 5-stopniową skalę, na której wartość 5 oznaczała bardzo częste występowanie, a 1 - brak występowania wskazanego zjawiska. Osoby pełniące funkcję sędziów w wypowiedziach dzieci określały za pomocą skali następujące środki językowe: podniesiony głos, przyspieszone tempo mowy, ostry/rozkazujący ton, ironia, przekrzykiwanie przerywanie w pół słowa, niedomówienie, zniekształcanie słów, przedrzeźnianie/aluzje, wulgaryzmy. Druga część dotyczyła oceny następujących zachowań u obserwowanych: 
skarżenie, krytykowanie, rozsiewanie plotek, reagowanie krzykiem na upomnienia, agresja fizyczna. Obie obserwacje trwały 1,5 godziny.

Celem badania pilotażowego było określenie języka i zachowań agresywnych stosowanych przez dzieci z rodzin dysfunkcyjnych. W związku z tym sformułowany problem badawczy brzmiał: jaka jest częstość występowania języka agresji i zachowań agresywnych u dzieci z rodzin dysfunkcyjnych w ocenie sędziów kompetentnych. Oceny sędziów kompetentnych zostały poddane analizie statystycznej za pomocą programu PQ-Start. Obliczono współczynnik $\bar{W}$ Kendalla oraz współczynnik korelacji monotonicznej Spearmana.

Pierwszy ważny wniosek z przeprowadzonego badania dotyczy zgodności oceny sędziów kompetentnych. Oceny osób dokonujących obserwacji zebranego materiału badawczego na temat języka agresji $(p=0,002)$ w pierwszej grupie dzieci są statystycznie zgodne. Siła tej zgodności jest wysoka i wynosi $\bar{W}=0,76$, podobnie jak średni współczynnik korelacji monotonicznej Spearmana $r_{s}=0,68$. Podobna siła zgodności wystąpiła w ocenie zachowań agresywnych $\left(p=0,03, \bar{W}=0,66, r_{s}=0,55\right)$.

Spośród wyszczególnionych środków językowych sędziowie najczęściej wskazywali na podniesiony głos ( $\bar{X}=4)$, przekrzykiwanie $(\bar{X}=4)$ oraz przedrzeźnianie $(\bar{X}=3,5)$. Najrzadziej występowały niedomówienia i wulgaryzmy $(\bar{X}=1,25)$. Wśród wskazanych zachowań najczęściej pojawiały się krytykowanie i agresja fizyczna, czyli bicie, popychanie itp. $(\bar{X}=4,25)$. Rozsiewanie plotek we wskazaniach sędziów występowało najrzadziej $(\bar{X}=1,25)$.

W grupie drugiej oceny sędziów kompetentnych dotyczące języka agresji $(p=0,000)$ również są zgodne. Siła tej zgodności jest wysoka i wynosi $\bar{W}=0,77$, podobnie jak średni współczynnik korelacji monotonicznej Spearmana $\left(r_{s}=0,70\right)$. Porównywalna siła zgodności wystąpiła również w ocenie zachowań agresywnych $\left(p=0,007, \bar{W}=0,69, r_{s}=0,62\right)$.

Spośród wyszczególnionych środków językowych sędziowie najczęściej wskazywali na podniesiony głos $(\bar{X}=5)$, przekrzykiwanie $(\bar{X}=5)$ oraz ironię ( $\bar{X}=3,6)$. Najrzadziej występowały niedomówienia $(\bar{X}=1,2)$ i zniekształcanie słów ( $\bar{X}=1,4)$. Wśród wskazanych zachowań najczęściej pojawiało się reagowanie krzykiem na upomnienia, zwracanie uwag $(\bar{X}=4,4)$ i krytykowanie ( $\bar{X}=3,2)$. Rozsiewanie plotek we wskazaniach sędziów pojawiało się najrzadziej $(\bar{X}=1,2)$.

Uzyskane wyniki pokazują, że w opinii sędziów kompetentnych w badanych grupach dzieci język agresywny przejawiał się poprzez podniesiony głos, przekrzykiwanie lub przerywanie wypowiedzi w pół słowa, 
przedrzeźnianie siebie nawzajem i stosowanie ironii. W przypadku zachowań agresywnych dzieci często reagowały krzykiem na upomnienia, krytykowały się nawzajem i stosowały agresję fizyczną.

\section{Wnioski}

Większość podopiecznych świetlic środowiskowych wywodzi się z rodzin dysfunkcyjnych. Prezentowane przez nich zachowania oraz język, którym komunikują się z otoczeniem, są odzwierciedleniem wzorców obserwowanych w najbliższym środowisku. Agresja werbalna i fizyczna jest powszechnie spotykanym problemem, którego rozwiązanie stanowi jedno z podstawowych zadań pracowników takich placówek. Na brak satysfakcjonujących efektów w tym obszarze składa się wiele różnych czynników. Są one związane m.in. z brakiem wiedzy na temat funkcji, jakie spełnia agresja u dzieci zarówno w kontekście indywidualnego, jak i grupowego funkcjonowania, oraz niedoborem narzędzi umożliwiających radzenie sobie z tym problemem.

Na podstawie uzyskanych wyników nie można wyciągać wniosków dotyczących większej grupy dzieci. Niemniej jednak zgromadzone dane wskazują, że w badanych grupach występowanie środków językowych oraz zachowań klasyfikowanych jako agresywne jest zauważalne i dostępne bezpośredniej obserwacji. Częstość takich środków językowych i zachowań jak przekrzykiwanie, podniesiony głos, przedrzeźnianie czy krytykowanie mogą wskazywać, że podstawową funkcją agresji werbalnej i niewerbalnej w badanych grupach dzieci jest dążenie do wypracowania odpowiedniej pozycji w grupie. W myśl zasady „im jestem głośniejszy, tym bardziej widoczny” dzieci starały się zaistnieć w czasie zajęć i pełnić rolę lidera. Przekrzykiwanie i wchodzenie komuś w słowo były bronią w walce o miejsce w grupie. Pojawiająca się krytyka służyła dewaluacji innych osób i wybicia się tym samym na lepszą pozycję. Dodatkowo, takie zachowania agresywne jak szturchanie, popychanie czy podstawianie komuś nogi służyły ośmieszeniu i ukazaniu drugiej osoby w gorszym świetle.

Mając na uwadze sytuację rodzinną i socjalną badanych dzieci, nietrudno uzasadnić używanie opisanych powyżej środków językowych. Nagromadzenie wielu negatywnych czynników powoduje, że dzieci podejmują różne sposoby na zwrócenie czyjejś uwagi. Odnosząc się do funkcji języka agresji, można stwierdzić, że tym, co w badanych grupach prawdopodobnie najbardziej skłania dzieci do jego stosowania, jest zaspokojenie potrzeby identyfikacji z grupą, a także obrona własnych wartości, które dają im 
poczucie siły. Dorastając w tak trudnych warunkach (małe mieszkania przy równocześnie dużej liczbie domowników), dzieci muszą „wywalczyć” każdą chwilę uwagi. Aby zostały zauważone, wzajemnie się przekrzykują, przerywają wypowiedzi i mówią podniesionym tonem głosu. Zachowania społecznie nieakceptowane, takie jak stosowanie agresji fizycznej czy wulgaryzmy, również mają na celu zainteresowanie swoją osobą, a w środowisku rówieśniczym pozwalają na zdobycie dominującej pozycji w grupie.

Obserwowane zachowania i sposoby komunikowania się w badanych grupach mogą być przydatne do sformułowania hipotez dotyczących trudności, z jakimi dzieci borykają się w swoim środowisku rodzinnym. Ponadto, analiza funkcji, jakie spełniają prezentowane przez nie zachowania, może być pomocna w przygotowaniu konkretnych form działania, które pozwoliłyby zmniejszyć częstość występowania agresji werbalnej i niewerbalnej u dzieci ze środowisk dysfunkcyjnych.

\section{Literatura}

Adler, R.B., Rosenfeld, L.B., Proctor II, R.F. (2007). Relacje interpersonalne. Proces porozumiewania się. Poznań: Dom Wydawniczy Rebis.

Brzezińska, A., Hornowska, E. (2004). Dzieci i młodzież wobec agresji i przemocy. Warszawa: Wydawnictwo Scholar.

Gajda, S. (2002). Agresja językowa w stosunkach międzyludzkich. W: W. Gruszyński (red.), Język narzędziem myślenia i działania (s. 59-66). Warszawa: Dom Wydawniczy Elipsa.

Goetz, M. (2014). Czym skorupka za młodu nasiąknie... Sprawcy przemocy rówieśniczej. Niebieska Linia, 5(94), 11-13.

Kielar-Turska, M., Białecka-Pikul, M. (2011). Wczesne dzieciństwo. W: B. Harwas- Napierała, J. Trempała (red.), Psychologia rozwoju człowieka. Charakterystyka okresów życia człowieka (s. 172-180). Warszawa: Wydawnictwo Naukowe PWN.

Krahé, B. (2005). Agresja. Gdańsk: Gdańskie Wydawnictwo Psychologiczne.

Kubacka-Jasiecka, D. (2009). Interwencja kryzysowa. Pomoc w kryzysach psychologicznych. Warszawa: Wydawnictwa Akademickie i Profesjonalne.

Majchrzyk, Z. (2002). O języku agresji. W: A. Wolska (red.), Wybrane problemy komunikowania się i komunikacji w zjawiskach patologii społecznej (s. 41-59). Szczecin: AMP Studio.

Morreale, S., Spitzberg, B., Barge, J.K. (2008). Komunikacja między ludźmi. Warszawa: Wydawnictwo Naukowe PWN.

Ostoja-Zawadzka, K. (1999). Cykl życia rodzinnego. W: B. de Barbaro (red.), Wprowadzenie do systemowego rozumienia rodzin (s. 18-30). Kraków: Wydawnictwo Uniwersytetu Jagiellońskiego.

Peisert, M. (2004). Formy i funkcje agresji werbalnej. Próba typologii. Wrocław: Wydawnictwo Uniwersytetu Wrocławskiego. 
Pereświet-Sołtan, A. (2013). Język agresji w mediach - aspekty psychologiczne. Rocznik Bezpieczeństwa Narodowego, 7, 306-312.

Prajsner, M. (2002). Rodzina dysfunkcyjna. Remedium, 5, 18-19.

Ryś, M. (2003). Psychologiczne źródła dysfunkcji w małżeństwie i rodzinie. W: W. Majkowski (red.), Rodzina polska u progu trzeciego tysiq̨clecia (s. 90-92). Warszawa: Wydawnictwo Uniwersytetu Kardynała Stefana Wyszyńskiego.

Taras, B. (2013). Badania nad agresją we współczesnym językoznawstwie polskim. W: B. Taras, Agresja. Studium semantyczno-pragmatyczne (s. 41-55). Rzeszów: Wydawnictwo Uniwersytetu Rzeszowskiego. 